\title{
HISTOPATHOLOGICAL CHANGES IN RAT LIVER AFTER A SINGLE HIGH DOSE OF ALUMINIUM*
}

\author{
Milka BOGDANOVIĆ ${ }^{1}$, Ana BEGIĆ JANEVA², and Petar BULAT ${ }^{1}$ \\ Institute of Occupational Health "Dr Dragomir Karajović", University of Belgrade School of Medicine', \\ Belgrade, Serbia
}

Received in September 2007

Accepted in May 2008

\begin{abstract}
Aluminium (Al) exposure may affect the liver of experimental animals. This investigation aimed at evaluating morphological changes in rat liver after a single high dose of Al (as metallic powder suspension). A total of forty female Wistar rats were divided in one exposed and one control group, 20 rats each. The exposed rats received $0.5 \mathrm{~mL}$ of sterile physiological suspension of fine Al powder in the concentration of $100 \mathrm{mg} \mathrm{mL}^{-1}$ intraperitoneally (50 mg Al per rat). After 7 weeks all animals were killed (by exsanguination from the abdominal aorta in ether anaesthesia). Liver aluminium was analysed using electrothermal atomic absorption spectrometry. For light microscopy the liver tissue was stained with hematoxylin and eosin, and for histochemical analysis with aurin threecarbocsillic acid (aluminon).

Liver Al level was markedly higher in the exposed $\left(37.1 \mu \mathrm{g} \mathrm{g}^{-1}\right)$ than in control rats $\left(0.71 \mu \mathrm{g} \mathrm{g}^{-1}\right)$. The exposed rats showed crystalloid Al inclusions in the capsular, subcapsular, and portal liver tissue. The basic liver structure remained intact. Slightly multiplied bile ductuli were found in 16 of 20 exposed and in 8 of 20 control rats. Three exposed rats had mycrovesicular steatosis. The peritoneum and Glisson's capsule showed strong macrophage infiltration and a foreign-body-like reaction with multiple giant macrophages containing Al crystalloid inclusions. Although this reaction was a defense against the metal, some Al passed this barrier and entered the liver tissue, exerting toxic effects in bile ductuli and hepatocytes.
\end{abstract}

KEY WORDS: bile ductuli, crystalloid aluminium inclusions, hepatotoxicity, Wistar rats

Aluminium (Al) is a silvery white, shiny, extremely reactive metal available everywhere in the environment, in the soil, water and air. It was discovered in 1827, and its production started twenty years later. Today aluminium is used in almost all industrial fields, agriculture, and traffic. Exposure to $\mathrm{Al}$ is almost inevitable, since it is present in water, air, and food, as well as in drugs, as an active substance or an additive. It was not until 1975 that $\mathrm{Al}$ attracted attention, when the first case of encephalopathy was associated with high quantities of Al in brain cells (1). This encephalopathy

\footnotetext{
* This paper has partly been presented at the International Symposium Safety and Health at Work in Metal Industry: 2007 - Focus on Aluminium Industry" held in libenik, Croatia on 24-26 May 2007.
}

was found in patients on chronic dialysis or in heavily exposed workers (e. g. welders). This encouraged a more intense research of Al toxic effects. Beside the brain, Al in high doses was also shown to damage the kidneys, bones, heart, and lungs (2-5).

Hepatotoxic effects of $\mathrm{Al}$ were considered less important, despite the fact that $\mathrm{Al}$ accumulates in macrophages and in hepatocyte organelles such as lysosomes $(3,6)$.

The aim of this study was to assess morphological changes in the liver tissue after parenteral exposure to $\mathrm{Al}$ (water suspension of pure Al powder). This research provided additional evidence to our clinical findings in workers occupationally exposed to Al. 


\section{MATERIALS AND METHODS}

Experimental research was conducted on 40 female two-month-old Wistar rats of similar body weight between $280 \mathrm{~g}$ and $320 \mathrm{~g}$. The rats were divided in two groups, 20 in the exposed and 20 in the control group.

The experimental protocol observed the Guide for the Care and Use of Laboratory Animals (7). Rats were kept in cages with a 12-hour light/dark cycle at controlled temperature $\left(21^{\circ} \mathrm{C}\right.$ to $\left.25^{\circ} \mathrm{C}\right)$, fed with standard rodent feed, and given tap water ad libitum. During a three-week quarantine no clinical changes in the appearance and/or behaviour were observed. Before the start of the experiment, one animal was killed from each cage, and post mortem findings confirmed that the animals were healthy.

Fine Al powder (aluminium metallic pulvis subtilis by Kemika Zagreb, Croatia) was suspended (100 $\mathrm{mg} \mathrm{mL}^{-1}$ ) in a sterile physiological solution, and $0.5 \mathrm{~mL}$ of suspension containing $50 \mathrm{mg} \mathrm{Al}$ was injected intraperitoneally to each rat in the exposed group. This dose was based on earlier investigations $(8,9)$.

Control rats did not receive anything at all. All animals were killed by exsanguination from the abdominal aorta in ether anaesthesia seven weeks after $\mathrm{Al}$ administration.

Liver was dissected from each animal and one part used to determine $\mathrm{Al}$ mass fraction per gram of wet liver tissue, while the other part was used for histological analysis. Liver tissue $\mathrm{Al}$ was determined using a electrothermal atomic absorption spectrophotomer (ET AAS) "Unicam" SP 90 A (10). Statistical differences between the exposed and control groups were analysed using Student's $t$-test.

For morphological observation by light microscopy liver tissues were fixed in $10 \%$ neutral formaldehyde solution, dehydrated in ascending ethanol series, and embedded in paraffin. Sections were stained with hematoxylin and eosin (HEE), and for histochemical analysis with aurin threecarbocsillic acid (aluminon) using Irwin's method $(10,11)$.

The analysis included basic liver structure, portal tracts, acini in sinusoidal and perisinusoidal spaces, and Glisson's capsule.

\section{RESULTS}

Average liver $\mathrm{Al}$ in the exposed rats was (37.1 \pm 14.72$) \mu \mathrm{g} \mathrm{g}^{-1}$ wet weight $(\mathrm{N}=11)$ and in controls $(0.71 \pm 0.22) \mu \mathrm{g} \mathrm{g}^{-1}$ wet weight $(\mathrm{N}=16)$.
Light microscopy showed that the basic liver structure remained intact. In the exposed rats, portal areas, which were of standard dimensions, had several gently pigmented, Al-positive macrophages (found in 18 of 20 samples). No macrophage was found in control liver samples. In 16 of 20 samples of the exposed and in eight of 20 samples of control rats, bile ductuli were slightly multiplied.

No specific changes were detected in the liver parenchyma in the exposed rats, but micro-vascular fatty changes were found in the hepatocytes of three (of 20) liver samples. No such changes were observed in control rat samples. Sinusoidal and perisinusoidal cells did not show any specific changes.

Glisson's capsule of the exposed rats showed a very strong macrophage reaction that looked like a reaction to a foreign body. It was evidenced by granulomatous changes, in which cells, often gigantic, were infiltrated by black rough Al particles of crystalloid structure. Granulomatous reaction with pigmentation, in fact crystalloid inclusions, was found in the subcapsular liver tissue, including the portal area (Figures 1, 2, and 3).

\section{DISCUSSION}

In experimental research, $\mathrm{Al}$ was administered orally, parenterally and intracranially to laboratory animals, but mainly in the form of $\mathrm{Al}$ compounds (12). In 1979, Ellis et al. (13) injected aluminium chloride intraperitoneally to laboratory rats, and noticed changes in the bones. These results were later confirmed by Goodman et al. (14)in 1984. Tetsuji and Kiyokazu (6) found that after oral administration of aluminium in water solution, $\mathrm{Al}$ accumulated in the liver, kidneys, and intestines, but not in the brain, and using an electronic microscope (EDX) they detected an accumulation of $\mathrm{Al}$ in lysosomes and vesicles of hepatocytes.

Until now most attention has been paid to experimental research of Al neurotoxic effects. There are a relatively small number of data related to $\mathrm{Al}$ toxic effects on the liver functionality and morphology. According to Galle et al. (15), Al does not produce toxic effects in the liver because it is eliminated from hepatocytes into the bile together with lysosomes.

On the other hand, Abubakar et al. (16) ascertained that $\mathrm{Al}$ in hepatocytes, even in small quantities, is associated with an increase in reactive oxygen species and lipid peroxidation. Gonzales et al. (5) pointed out a hepatocyte dysfunctionin terms of reduced 


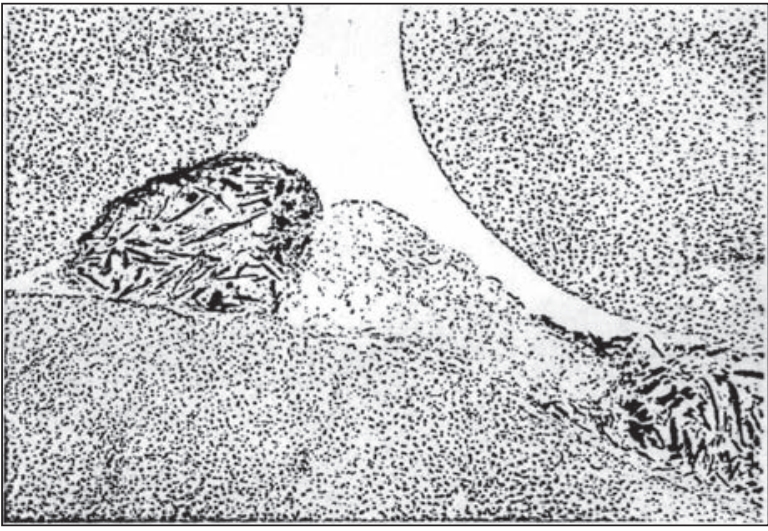

Figure 1 Stained subcapsular liver granulomatous reaction in rats administered a single peritoneal injection of suspended aluminium (staining by aluminon; magnified 63x)

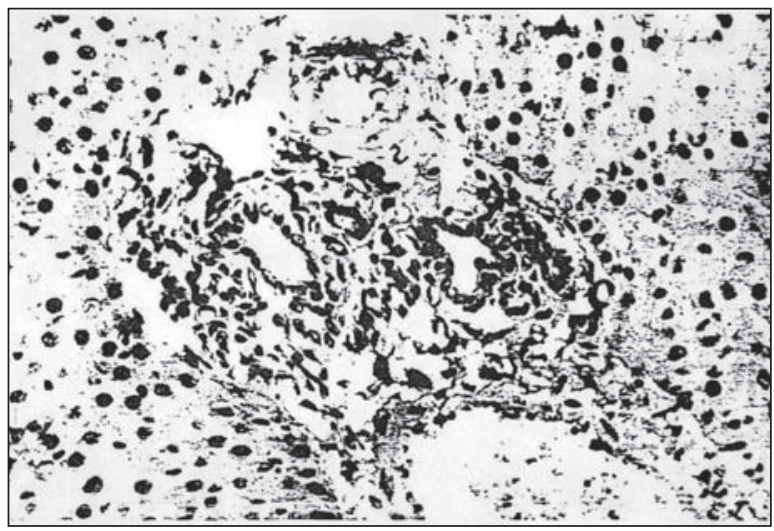

Figure 2 Slightly multiplied bile ductuli in in rats administered a single peritoneal injection of suspended aluminium (staining by HEE eosin; magnified 320x)

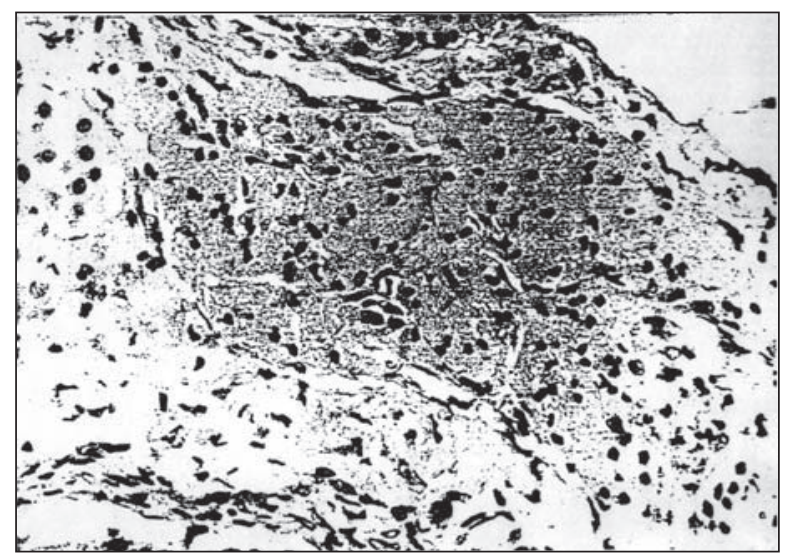

Figure 3 Liver portal area with stained phagocytes in rats administered a single peritoneal injection of suspended aluminium (staining by HEE and aluminon; magnified 320x)

organic molecule transport over the sinusoidal and bile canalicular membrane, which leads to unbalanced bilirubin and bile acid.

Our study has shown that intraperitoneal injection of suspened pure Al significantly increased its concentration in the liver tissue of the exposed rats. This suggest that Al was absorbed and deposited in the liver. It penetrated the liver through Glisson's capsule, and lymph.

Furthermore, histochemical staining showed that $\mathrm{Al}$ accumulated in phagocytes of the portal area (macrophagocytes and Kupffer cells) as well as in macrophagocytes of the subcapsular area. It was not observed in either the cytoplasm or the organelles of hepatocytes. Even if Al did accumulate in the organelles, and especially in lysosomes, its quantities were too small to be stained by aluminon. Larger particles behaved as a strange body and were immediately overtaken by macrophagocytes. In the capsular and subcapsular area, where Al was detected, the granulomatous reaction was significant.

In addition to changes in Glisson's capsule and in the subcapsular area in the exposed rats, specific changes were also observed in the portal area and acini, which were not seen in the liver of the control animals. These changes included slight microvascular fatty changes, Kupffer cell hyperplasia, and multiplication of bile canalicules, showing that $\mathrm{Al}$ reached all liver structures. This suggest that some metal particles passed the macrophagocyte barrier.

\section{CONCLUSION}

Our results have demonstrated that $\mathrm{Al}$ injected intraperitoneally accumulates in the liver of experimental rats. Only in these rats did we detect morphological changes in the liver tissue such as slight proliferation of bile ductuli and microvesicular steatosis.

Even though abnormal experimental Al exposure such as ours usually does not occur in human beings, our finding may help in further investigations of $\mathrm{Al}$ hepatotoxic effects.

\section{REFERENCES}

1. Sjögren B, Iregren A, Elinder C-G, Yokel RA. Aluminum. In: Nordberg GF, Fowler BA, Nordberg M, Friberg L, editors. Handbook on the Toxicology of Metals, $3^{\text {rd }}$ ed. Amsterdam-Tokyo: Academic Press; 2008. p. 339-65.

2. Hathaway GJ, Proctor NH, Hughes JP, Fischman mL. Proctor and Hughes' Chemical Hazards of the Workplace. $3^{\text {rd }}$ ed. New York (NY): Van Nostrand Reinhold; 1991.

3. Vidaković A, editor. Profesionalna toksikologija [Occupational Toxicology, in Serbian]. $1^{\text {st }}$ ed. Beograd: GIP Elvod-print; 2000. 
4. Campbell A. The potential role of aluminium in Alzheimer's disease. Nephrol Dial Transplant 2002;17(Suppl 2):17-20.

5. Gonzalez M, Roma mg, Bernal CA, Alvarez AM, Carrillo MC. Biliary secretory function in rats chronically intoxicated with aluminum. Toxicol Sci 2004;79:18995.

6. Tetsuji N, Kiyokazu K. Aluminium accumulation in the human body and experimental animals. J Health Environ Sci 2005;1:12-48.

7. Directive $86 / 609 /$ EEC on the protection of animals used for experimental and other scientific purposes. European Commission, 1986. URL: ec.europa.eu/ food/fs/aw/aw_legislation/scientific/86-609-eec_en.pdf [Retrieved 8 February 2007]

8. Jeffery EH, Jansen HT, Dellinger JA. In vivo interactions of aluminum with hepatic cytochrome P-450 and metallothionein. Fundam Appl Toxicol 1987;8:541-8.

9. Klein GL, Heyman MB, Lee TC, Miller NL, Marathe G, Gourley WK, Alfrey AC. Aluminum-associated hepatobiliary dysfunction in rats: Relationships to dosage and duration of exposure. Pediatr Res 1988;23:275-8.

10. Bogdanović M. Prilog poznavanju hepatotoksičnih efekata metala u uslovima hronične, profesionalne ekspozicije [Hepatotoxic effects of chronic, occupational exposure to metals, in Serbian]. [PhD thesis]. Belgrade: University of Belgrade School of Medicine; 1991.

11. Nagata T. Special cytochemistry in cell biology. In: Jeon KW, editor. International review of cytology. New York: Academic Press; 2001.

12. Spencer AJ, Wood JA, Saunders HC, Freeman MS, Lote CJ. Aluminium deposition in liver and kidney following acute intravenous administration of aluminium chloride or citrate in conscious rats. Hum Exp Toxicol 1995;14:787-94.

13. Ellis HA, McCarthy JH, Harrington B. Bone aluminum in hemodialyzed patients and in rats injected with aluminium chloride: Relationship to impaired bone mineralization. J Clin Pathol 1979;32:832-5.

14. Goodman WG, Jeanenne G, Horst R. Short term aluminum administration in the rat: Efects of bone formation and relationship to renal ostheomalacia. J Clin Invest 1984;73:171-3.

15. Galle P, Guidicelli CP, Nebout T. Ultrastructural localisation of aluminium in hepatocytes of hemodialyzed patients. Ann Pathol 1987;7:163-70.

16. Abubakar mg, Taylor A, Ferns GA. Aluminium administration is associated with enhanced hepatic oxidant stress that may be offset by dietary vitamin $\mathrm{E}$ in the rat. Int J Exp Pathol 2003;84:49-54. 


\title{
Sažetak
}

\section{PATOHISTOLOŠKE PROMJENE U JETRI ŠTAKORA NAKON JEDNOKRATNOG IZLAGANJA VISOKOJ DOZI ALUMINIJA}

\begin{abstract}
Izloženost aluminiju (Al) može izazvati oštećenje jetre u eksperimentalnih životinja. Cilj istraživanja bio je procijeniti morfološke promjene u jetri štakora nakon jednokratnog davanja visoke doze aluminija (suspenzije metalnog praha). Četrdeset albino Wistar štakorica bilo je podijeljeno u izloženu i kontrolnu skupinu. Izloženoj skupini ubrizgano je intraperitonealno $0,5 \mathrm{~mL}$ sterilne suspenzije praha aluminija u fiziološkoj otopini (100 mg mL-1), odnosno $50 \mathrm{mg} \mathrm{Al} \mathrm{po} \mathrm{štakorici.} \mathrm{Nakon} \mathrm{sedam} \mathrm{tjedana} \mathrm{štakorice} \mathrm{su} \mathrm{usmrćene}$ (iskrvarenjem iz trbušne aorte u eterskoj narkozi). Maseni udio Al u tkivu jetre određen je atomskom apsorpcijskom spektrometrijom. Histološka analiza svjetlosnom mikroskopijom obavljena je nakon bojenja tkiva hematoksilinom i eozinom te histokemijski aurin trikarboksilnom kiselinom (aluminonom). Maseni udio aluminija u jetri izloženih štakorica bio je viši $\left(37,12 \mu \mathrm{g} \mathrm{g}^{-1}\right)$ nego u kontrolnoj skupini $\left(0,71 \mu \mathrm{g} \mathrm{g}^{-1}\right)$. U izloženih štakorica nađene su kristaloidne inkluzije Al u kapsularnoj i supkapsularnoj zoni jetre i u portalnim prostorima. Osnovna struktura jetre je ostala očuvana. U 16 od 20 izloženih i u 8 od 20 kontrolnih štakorica opažena je proliferacija žučnih kanalića. Samo u tri izložene štakorice nađena je mikrovezikularna steatoza u jetrenom tkivu. Peritoneum i fibrozna (Glissonova) ovojnica jetre pokazivali su izrazitu infiltraciju makrofazima sličnu "reakciji oko stranog tijela" s mjestimičnim gigantskim stanicama u kojima su se nalazile kristaloidne inkluzije Al. lako je infiltracija makrofaga obrambena reakcija kojom je najveći broj čestica Al zadržan na mjestu ubrizgavanja, čini se da je dio tih čestica prodro u tkivo jetre i izazvao toksične reakcije u obliku proliferacije žučnih kanalića i mikrovaskularne steatoze.
\end{abstract}

KLJUČNE RIJEČI: aluminij, hepatotoksičnost, kristaloidne inkluzije aluminija, laboratorijske štakorice, proliferacija žučnih kanalića

\section{CORRESPONDING AUTHOR:}

Milka Bogdanović, $\mathrm{MD}, \mathrm{PhD}$

Institute of Occupational Health "Dr Dragomir Karajović"

Deligradska 29, 11000 Beograd, Serbia

E-mail:mlkbogdanovic@yahoo.com 